\title{
ESTATE PLANNING UNDER THE NEW LEGISLATION FRANK JONES*
}

The withdrawal by Federal Government from the estate tax field and the fact that Alberta does not levy Succession Duties or a Gift Tax, do not mean that estate planning has ceased to be vital. In this article Professor Jones outlines some effects of the new Income Tax Act in regard to taxes which become exigible upon death. Particular emphasis is placed on the effect of section 70 on the disposition of capital gains and the new concept relating to valuation contained in section 164(6). In addition, the article discusses several techniques to minimize or reduce taxes payable, such as the estate "freeze", the tax-free "roll-over"for property passing to a spouse, the transfer of non-capital assets to beneficiaries, the importance of assets being situated in Alberta, the usefulness of the corporate "freeze" and the lawyer's role in the "evaluation of assets" process.

Is estate planning for Alberta residents still necessary after the withdrawal of the Federal Government from the estate tax field? Since Alberta has not enacted a Succession Duty or Gift Tax Act do we in Alberta have to concern ourselves with planning to lessen the impact of taxes at death? The answer to both these questions is, of course, a resounding "yes". While it is true that in Alberta residents do not have to worry about a Succession Duty or Gift Tax, for anyone the least bit aware of the provisions of the new Income Tax Act it is obvious that one needs to plan both one's own and one's clients' affairs in order to minimize and, in some cases, eliminate capital gains tax which will be exigible upon death. One other area with which lawyers must make themselves familiar is the filing of the necessary tax returns upon death. If the legal profession is to perform its responsibility and to retain its traditional role, it is essential that lawyers take time from their busy practice in order to acquaint themselves with the new provisions in order to advise their clients and to perform the duties necessary to protect them and their heirs at the time of death.

There is a distinct possibility of the necessity of filing several separate tax returns on behalf of the deceased, which returns must be filed within six months after death. Two situations under the new act continue the right of the personal representative to split the income of the deceased during the year of death. A "rights or things" return must be filed and an election may be made by the personal representative within one year after the date of death or within ninety days after the mailing of an assessment related to the terminal period, to be taxed as a separate person in relation to the value of such "rights or things". 1 It is seen, therefore, that the taxable income so generated by the "rights or things" will be subject only to the marginal rates as though this were the only income of a separate and distinct individual taxpayer.

The second situation is found in paragraph $104(23)(d)$ of the Transitional Rules and relates to property income of the deceased as a beneficiary of a testamentary trust. Where the fiscal period of the trust is not a calendar year and the deceased dies between the fiscal year end of the trust and December 31, the income from such source be-

\footnotetext{
- Professor of Law, Faculty of Law, University of Alberta.

I Income Tax Act, S.C. 1972, s. 70(2).
} 
tween the trust's year end and his date of death may be calculated as if the source were the deceased's only source for the year.

An additional income split is found relating to business income of the deceased as owner or partner in a business. ${ }^{2}$

These situations produce income splits of significance and it is submitted that one should consider the advantage of a January year end for a trust where one of the income beneficiaries of the trust is ageing. In addition, a January year end for a partnership whose partners range in age could be useful in availing the estate of a deceased partner of the income splitting opportunities. It has been pointed out ${ }^{3}$ that there is a deterrent to the use of one of these provisions under subparagraph $118(3)(\mathrm{d})(\mathrm{ii})$ in which it is provided that the general income averaging rules as set out in subsections (1) and (2) of section 111 are unavailable where the personal representative has availed himself of the election in section $70(2)$ relating to "rights or things". It seems incongruous that the income split available under section 70(2) should have this result flow from it but this result does not follow from similar income splittings under section $104(23)(d)$ or $150(4)$.

As will be discussed later when talking about estate planning, section 70(5) of the Income Tax Act introduced for the first time in Canada a deemed disposition at death insofar as capital gains are concerned. This has particular significance in preparing the terminal period returns for a deceased taxpayer. The deemed disposition so envisaged by the Act will be by the deceased to the executor of his estate with the actual disposition by the executor either to the beneficiaries or to others when he sells to pay debts, etc. To avoid a double taxation there is a tax free "roll over" 4 when the second disposition is made from the executor to the beneficiary. In essence, the executor is deemed to have realized sums equal to his adjusted cost base with the executor's adjusted cost base being passed onto the beneficiary. Thus, any potential capital gains will accrue to the beneficiary upon his disposition of the property received from the executor.

\section{Taxes on Death}

Section 70 of the new Income Tax Act is the one most directly connected with taxes exigible upon the death of an individual. As stated above, there is a deemed disposition of all capital gains. Depreciable and non-depreciable property are dealt with in different manners relating to this deemed disposition. With respect to nondepreciable property the disposition is deemed to have taken place at the fair market value as of the date of death. Therefore, all capital gains which had accrued to the individual during his lifetime will be taxed at his death. If, for instance, an individual purchased a piece of land in 1972 the adjusted cost base of which was five thousand dollars and its fair market value at death in 1980 was ten thousand dollars, the deemed disposition of this asset would result in onehalf of the capital gain which had accrued during his lifetime being taxed as income in the year of his death. The same result will happen with respect to shares in a private family business. It is seen, therefore,

\footnotetext{
2 Id. s. 150(4).

3 See J. A. Langford, Tax Reform and the Death of a Tax Payer.

- Income Tax Act, supra, n. 1 8. 107(2).
} 
that the more successful the investment or business is, the more acute the tax liability at death, if no planning is done.

With respect to depreciable property, again there is a deemed disposition but the disposition price is a point midway between the undepreciated capital cost of the asset and its fair market value at death. There will, therefore, be a recapture with income tax payable on it if the fair market value is greater than the undepreciated capital cost. ${ }^{5}$ If the fair market value is considerably higher than the original purchase price, there may be in addition to the recapture a capital gains tax payable. To say, therefore, that we in Alberta do not have to concern ourselves about tax liquidity at death is wrong. It may well be that a private family business may have to be sold in order to pay the capital gains tax and recapture capital cost allowance exigible at death if the necessary forethought has not gone into the planning of the estate.

The major exception to the above relates to property passing directly to a spouse or to a trust for a spouse. In such a case there is a tax free "roll over" and any capital gains tax and/or recapture of capital cost allowance is postponed until the death of the surviving spouse. In order for the trust to so qualify, the spouse must have the exclusive use of the property during his or her lifetime. This does not mean to say that the trust may be discretionary insofar as the use of the capital or income is concerned, but it does say that only the surviving spouse may have the benefit of such discretion during his or her lifetime. A remainder-man clause may be put into the trust providing for the disposition of both the capital and income after death of the spouse without "tainting" the trust insofar as the Income Tax Act is concerned. The trust or spouse is deemed to have acquired the property at the deceased's undepreciated capital cost or adjusted cost base as the case may be. Consequently, any recapture or capital gains will be levied against the trust or spouse upon disposition during the spouse's lifetime or upon deemed disposition at his or her death.

A potentially serious problem exists under the wording of section $70(5)$ relating to the situation of joint tenancies. Upon the death of one of the joint tenants section 70(5)(a) indicates clearly that the deceased is deemed to have disposed of his interest. Capital gains tax will therefore have to be paid and if the property is depreciable any recapture as per the above rules will take place, assuming that the joint tenants were not married. However, it is open to question as to whether or not the surviving tenant will have his adjusted cost base increased as a result of the death of the other joint tenant. The value of his holding has increased due to the fact that he is now the sole tenant of the asset but if one applies the words of section 70(5)(c) literally, the successor may not have acquired anything by virtue of the death of the deceased and hence his adjusted cost base may not be increased. The result of this may be that the successor (be he a spouse or not) will have only an adjusted cost base of one-half the value of the asset and yet will be taxed on the fair market value of the asset as a whole upon his death or upon the asset's disposition during the survivor's life. Both joint tenants start out with an undivided interest in the whole. When one dies the other still has an undivided interest in the whole

\footnotetext{
s Id. 8. 7O(5)(b).
} 
but it is worth more because he is the only person in that position. The value has changed but his legal interest has not. Has he, therefore, in law "acquired" anything which he did not have before?

A new concept in the Act relates to the many valuation problems and arguments which undoubtedly will arise because of the deemed realization concept. An executor has additional flexibility in dealing with valuation under section 164(6). In the case of a capital loss or a terminal loss he may elect to apply this loss either to the income previously calculated for the deceased's terminal period or elect that it be applied to the tax that would have been payable on account of the tax due for the estate's first year. When one combines this with the income splitting techniques available at death enumerated above, it is readily seen that by the proper application a considerable tax minimization may be accomplished through the proper use of these elections.

At the year of death, capital losses are deductible not only from capital gains but also from all other income of the terminal year without limit in amount. ${ }^{6}$ In addition, if there are still capital losses left over they may be applied to the preceding taxation period and again applied to other income of that year without limit. This "no limit" concept is, of course, in direct contrast to the norm which allows only a maximum of one thousand dollars of capital losses to be claimed against other income.

The personal representative may elect to spread the payment of any tax exigible at death up to six equal consecutive annual payments. The first of such payments is to be made on the day when the tax would ordinarily be payable with the balance being made on the anniversaries of the day when the first would have been made. ${ }^{7}$

Consequently the lawyer for the estate should be aware that these various rights - to split income; to revise the fair market value at death in light of post mortem market value; to deduct all prior capital gains in the terminal and penultimate period; the spreading of tax payments over a six year period-are available to his client and should be used to the maximum in order to minimize the tax impact at death.

\section{Estate Planning}

Having briefly set out the tax consequences which flow upon death, let us investigate what techniques are available to minimize or reduce the taxes payable. The well-known concept of an estate "freeze" is equally valid when considering the impact of capital gains at death. If an estate can be "frozen" at a value in which there is little or no capital gain inherent in it then the potential capital gains tax can, in effect, be postponed for a whole generation. Under the old estate "freeze" one of the most frequently used methods was to capitalize a corporation with preferred and common shares-the preferred shares going to the person wishing to "freeze" his estate and the common shares, going to his wife and children. Due to the fact that property can be passed tax free to a spouse, there is little need for the spouse to be a common shareholder in that an individual may pass directly property which he wishes his spouse to have and there is no need to indirectly benefit the spouse by the spouse being a common share-

- Id. 8. 111(2).

7 Id. 8. 159(4) to $8.159(6)$. 
holder when this can be done directly. If "freezes" are done shortly after valuation day and there is little or no capital gains in the assets transferred, the "freeze" may be accomplished in a manner similar to that which was in vogue previously. If, however, a person does not come to his solicitor for estate planning advice until a considerable length of time has passed since valuation day, with the consequence that there has been a significant appreciation since valuation day in the assets to be transferred into the "freeze" company, a slightly different timing technique must be used. The individual wishing to "freeze" his estate may use provisions of section 85 of the Income Tax Act to achieve a tax free "roll over" but the provisions enunciated therein must be strictly complied with. One of these provisions is that the transferor must own at least $80 \%$ of all classes of shares issued by the corporation "immediately" after the transfer. Under the old system of accomplishing a freeze, this would not be the case due to the fact that the individual would not own any of the common shares since these were all being held by his wife and children. Under the new act it is therefore necessary, in order to qualify under section 85 , that the individual issue only preferred shares at the time of transfer and of course he will take $100 \%$ of these and thus qualify under the $80 \%$ rule. Common shares may later be issued to the children. How much later is a matter of conjecture at this point in time. The word used in section 85 is "immediately". Until the courts have had the chance to judicially interpret what this word means it is advisable to err on the safe side. It is suggested, therefore, that if common shares are issued three months after the transfer of the assets into the "freeze" corporation, section 85 will be complied with. It is to be noted that these common shares must be paid for by the children with their own funds and not funds given to them by their parent if the children are under eighteen. If the funds are given to the children by the parent and the child is under eighteen the attribution rules will apply and if the parent should die there will be a deemed realization of his capital gains, one-half of which are classified as income, and these will be taxed in the transferor's hands rather than in the children's.

It is also to be noted that the children must pay the current fair market value of the common shares. This fair market value must account for any appreciation of the assets which has taken place between the initial transfer into the corporation and the issuance by the corporation to the children of common shares. Normally this will not be of any significance but if shares in public companies are part of the assets transferred to the "freeze" company and there has been a substantial appreciation in their market value, this appreciation must be recognized in the value attached to the common shares issued to the children.

One of the advantages in the "freeze" type corporation is the flexibility which may be built into this type of vehicle. For instance, if the transferor wishes income, he may declare a dividend only on the preferred shares and thus receive all of the income he desires. If, however, he wishes to have income go to the children he may declare dividends only on the common shares, or a combination of the two may be used. If the corporation is in receipt of dividends on common shares held by it, this will be taxed as investment income and the tax paid by the corporation will be refundable to the corporation if dividends 
are declared by it to its shareholders. Therefore, an integration concept applies in the "freeze" corporation. Trusts may be used as the owners of common shares with dividends being declared to the trust. The trust will be taxed at 50\%, however, the trust and "preferred beneficiary" may jointly elect in respect to the taxation year that all or part of the trust's accumulating income may be included in the beneficiaries' income for the year. ${ }^{8}$ If, therefore, the beneficiaries of the trust are in a relatively low rate, the income generated to the shareholder (i.e. the trust) may be split between the trust and the beneficiaries.

Section 104(15) defines a "preferred beneficiary" as:

Under any trust means an individual resident in Canada who is a beneficiary under the trust and is

(i) the settlor of the trust

(ii) the spouse or former spouse of the settlor of that trust or

(iii) a child, grandchild or great grandchild of the settlor of the trust, or the spouse of any such person

It should be remembered, however, that if the shareholders of the "freeze" company are a trust the twenty-one year revaluation rule will come into effect under the new act with a deemed realization of capital gains taking place at the end of each twenty-one year period. Care should, therefore, be taken in using trusts as shareholders of "freeze" companies.

It is common practice that, in addition to the preferred shares, the transferor takes back from the "freeze" company, notes. Caution should be taken with respect to such notes due to the fact that if under section 80 of the new Act the note is forgiven the debtor and intended beneficiary may find that either his loss position or his cost base has been reduced. Although it was apparently not intended that section 80 should apply to this situation, this appears to be the result and notes should not be forgiven until the matter is clarified. On the other hand, section 80 can be avoided by making a cash gift to the debtor and having him repay the note.

In the case of partnerships and private companies, it is common for the partners or shareholders to enter into buy-sell agreements so that the survivor can acquire the deceased's interest or shares on death and to ensure that the estate of the deceased has sufficient funds to pay the applicable death duties. A common problem in this area is that the agreed transfer price is often less than the fair market value at death of the property transferred. It has become usual to exclude property which was the subject matter of a buy-sell agreement from the tax exoneration clause in a will. If this was done, to the extent that the contract price was less than the fair market value, the purchaser was made liable for the tax under section 14 of the old capital Estate Tax Act.

Under the new Income Tax Act, section 70(5) provides for a deemed realization of non-depreciable capital property at death for proceeds equal to its "fair market value" and taxes will have to be paid on any accrued gains. The question which must be decided in the case of a 
buy-sell agreement is whether or not the "fair market value" of the property transferred is equal to

(a) the contract price, or

(b) the fair market value of the property determined as if there were no contract with the surviving partner or shareholder.

The results of the judicial decisions relating to this problem appear to support that alternative (a) is the more likely possibility. ${ }^{9}$ It will be seen, therefore, that in the case of a buy-sell agreement where the purchase price under the agreement is less than the fair market value, the deceased's estate will receive only the contract price and yet will be liable for the capital gains tax on the full fair market value of the shares at the time of death. To avoid this, a buy-sell agreement should be reworded so that the survivor who is getting a bargain due to the fact that he is obtaining shares at less than their real worth should be responsible for any capital gains tax exigible to the deceased's estate over and above the contract price.

If an estate "freeze" is, in fact, accomplished any accretion in the property subsequent to the "freeze" will by operation of law go to the common shareholders. Therefore, any capital gains tax which could be levied on this accretion will not be exigible until the common shareholders have "disposed" of their assets or until the corporation has disposed of the underlying assets. This, of course, is of great advantage due to the fact that when either the corporation or the shareholders have made such a "disposition" they will have received cash or assets which could be converted into cash in return for their "disposition". They will then be in a position to pay any tax exigible at that time. Unlike death, which triggers a deemed disposition where in reality no liquid assets are available to pay the tax, the advantages are obvious.

As mentioned previously, a tax-free "roll over" exists for property passing to a spouse. Where, however, the widow or executor is obliged to realize capital properties to pay the debts and honour other specific bequests, there will be a deemed disposition at fair market value or half-way between that price and the undepreciated capital cost in the case of depreciable property with the usual consequences in the terminal return. The deceased's personal representative is obliged to pay his debts as a matter of law and will need assets in order to meet these obligations. In the ordinary mix of assets a new solution appears. This entails making a new type of split in the will between properties of the deceased that will not in fact, or cannot in law, produce a capital gain (i.e. insurance proceeds and other property that is not capital property, cash or securities for instant cash) and the rest of the property assets. The executor should be directed to resort to the former to pay debts or duties and to satisfy specific cash bequests, being permitted where necessary to convert such assets into cash for these purposes. As to the other assets, the executor might be directed to distribute them to the exclusive spouse trust without conversion into money.

Such a split suggests the fundamental change that must occur in the mind of tax-conscious draftsmen of wills. The new Capital Act directs them to consider and dispose of specific properties and sets of

Beaument v. M.N.R. 70 D.T.C. 6130. 
properties owned by the deceased, permitting some to be converted into money and prohibiting the conversion of others.

As stated previously, non-capital assets of the deceased must be accounted for under a "rights or things" return. Section 70(2) of the Income Tax Act reads:

Where a taxpayer who has died had at the time of his death rights or things (other
than any capital property or any amount included in computing his income by vir-
tue of subsection (1)), the amount whereof when realized or disposed of would
have been included in computing his income, the value therefore at the time of death
shall be included in computing the taxpayer's income for the taxation year in which
he died, except that where his legal representative has, within one year from the
date of death of the taxpayer or within 90 days after the mailing of any notice
of assessment in respect of the tax of the taxpayer for the year of death, whichever
is a later day, so elected, a separate return of values shall be filed and tax thereon
shall be paid under this Part for the taxation year in which the taxpayer died as if
he had been another person entitled to the deductions to which he was entitled
under section 109 for that year.

If such assets form a substantial portion of the estate, it would be wise, when drafting a will, to consider the possibility of section 70(3) which provides that:

Where before the time of making an election under subsection (2) has expired, a right or thing to which that subsection would otherwise apply has been transferred or distributed to beneficiaries or other persons interested in the estate or trust, subparagraph (a) subsection (2) is not applicable to that right or thing, and (b) an amount received by one of the beneficiaries or other such persons upon the realization or disposition of the right or thing shall be included in computing his income for the taxation year in which he received it.

It is seen, therefore, that the tax liability in the case of non-capital assets can be transferred to the beneficiary. The beneficiary will acquire the deceased's cost base and will only be taxable upon the sale of the assets. Since this is a relatively beneficial result, as opposed to the treatment of capital profits and properties, it gives rise to the rather startling situation where taxpayers will be arguing at death that certain assets constituted inventory rather than the usual situation where they would argue that they were capital properties. It is incumbent upon the lawyers for the estate to look at these assets and ascertain if such an argument would be advantageous in the particular circumstances.

One other area which must be kept in mind by solicitors advising clients with respect to their estate matters is that it is even more important today to have all the assets situated in Alberta. All of the provinces except Alberta levy a succession duty and gift tax and there is no need for an Alberta domicilary and resident to pay any taxes exigible by any of the other provinces. One of the ancillary benefits to an estate "freeze" corporation is that the situs of all the assets in the "freeze" company is consolidated in Alberta insofar as other provinces" death duty legislation is concerned. It should be noted that the situs rules enunciated under the Estate Tax Act are, of course, no longer applicable and we are back to the situation of ascertaining under the common law where the situs of certain assets is. Probably the two most complicated problems in this area are to ascertain the situs of a trust and to ascertain the situs of public company shares. Insofar as the share problem is concerned, again the "freeze" company for the most part solves any problems inherent in having such assets. With respect to the trust problem there are various conflicting authorities as to where 
the situs of a trust is but again it is wise to err on the side of ensuring the trust be situated in Alberta by having its business conducted here and having trustees resident in Alberta.

In the light of recent jurisprudence ${ }^{10}$ it is obvious that care must be taken in setting up such a "freeze" company, for example, the usual precautions to negate the concept of the Barber case should be taken. Of particular note, is the Winram case in which Mr. Justice Gibson stated that the holder of the majority of the voting shares of a corporation could have paid a dividend of the surplus of the corporation upon such shares despite the objections of the only other director and holder of voting shares, his wife, who also held all the non-voting shares of the corporation. It appears that the court must have accepted the principle that a majority shareholder was competent to dispose of the surplus of a corporation if he could have elected a new board of directors and then could have paid a dividend. It is equally important to note, however, that the wording of the Income Tax Act is not "competent to dispose" which was the wording that many of these cases were decided under, with respect to the Estate Tax Act, but is rather "disposition" (deemed or otherwise) and hence, some of the wider concepts enunciated under the former wording will not apply under the new wording which is, it is submitted, more restrictive.

One of the disadvantages of the corporate "freeze", as suggested above, is that if in fact any of the preferred shares are redeemed, it would probably throw the corporation into a paid-up capital deficiency which would then trigger a deemed dividend which would be taxable in the taxpayer's hands. ${ }^{11}$ It has been suggested by some commentators 12 that by the use of the tax-free "roll over" provisions contained in section 86 , with respect to capital reorganizations, a "freeze" company could be set up with preferred and common shares and one would thus avoid the paid-up capital deficiency problem.

To put the corporate "freeze" in its proper perspective the disadvantages of a corporate form should not be ignored. These have been well set out by J. D. McKellar as follows: ${ }^{13}$

(a) An individual but not a corporation can deduct $\$ 1,000.00$ of capital losses against other income. These deductions may be made in the current year. The taxpayer is also entitled to a one year carry back and an unlimited carry forward.

(b) The death of a controlling shareholder results in a change of control and no further loss carry forwards.

(c) Certain of the averaging provisions, including the general averaging provisions of section 118 of the Income Tax Act, are only available to individuals.

(d) Generally speaking, the courts have held that it is more difficult for a company to make a capital gain, as opposed to a fully taxable gain, than it is for an individual to do so. This is especially true in connection with a real estate transaction. Perhaps the position which the courts have taken in these matters may change in view of the imposition of a capital gains tax.

(e) There may be double taxation upon the death of a shareholder in respect of a corporation accrued but unrealized taxable gains. Assume, for example, that a shareholder acquired shares in a company at a cost of $\$ 100.00$ when the company's property had that value. If, on the shareholder's death, the assets of the company, including goodwill, were worth $\$ 100,000.00$, the shares of the company

10 Barber v. M.N.R. 66 D.T.C. 315; Beaument v. M.N.R., supra, n. 9; Patterson v. M.N.R. 69 D.T.C. 711; Fiddes Estate v. M.N.R. 70 D.T.C. 117; and Winrum Estate v. M.N.R. 72 D.T.C. 6187.

"Income Tax Act, supra, n. 1 s. 89.

12 M.A. Mogan, address to the Continuing Legal Education Seminar. Banff, Alberta, May 1972.

1.3 J. D. McKellar in The Family Business and the Corporation - Estate Planning and Administration, June 1972, The Law Society of Upper Canada, Department of Continuing Education. 
may well be valued with reference to that amount, ignoring the corporate taxes that may be payable on the gain when it is realized. This is particularly likely to be the case if there is a substantial goodwill factor. If subsequently the corporation disposes of its property, it too will be subjected to a tax. If goodwill is held by an individual, it may not be a "right or thing" and taxable at death within the provisions of section $70(2)$. In any event, it would not be taxable on death if transferred directly to the beneficiaries. (section 70(3)).

If the corporation realized a capital gain before the death of the shareholder and promptly distributes it to its shareholders, the integration provisions of the Income Tax Act normally insure that only one set of taxes is paid.

If the shareholder dies before capital gains are realized in the corporation, as long as the shares pass to executors, the assets of the corporation could be sold, then the shares themselves could be disposed of. If the executors have power to do both of these things and do so within twelve months from the date of death of the deceased, section 164(6) of the Income Tax Act provides that in most cases the tax paid on the deemed realization on death may be recovered. All this requires prompt payments, realizations, payments of dividends, etc. by astute executors.

If the section 85 "roll over" election with preference shares is used, it may be impossible to avoid some taxation at the death of the preferred shareholder since the accrued capital gains are probably partly reflected in the preference shares and partly in the common shares: ${ }^{14}$

(f) A holding company is not always the solution in every instance. Where a taxpayer is using the tax free zone method of valuation and his assets have a cost which exceeds the valuation day price, there may be problems if the assets are transferred to a holding company. It would appear that by reason of section 26(5) of the transition rules, the holding company will inherit the taxpayer's cost and not realize a taxable gain unless the sale price exceeds the capital cost. It seems that the gain can only be realized by the taxpayer by way of a taxable dividend from the company. Even if the taxpayer sells his shares of the holding company there will be a gain equal to the amount received above the fair market value of the assets when originally transferred to the company.

On balance, however, the consensus of opinion amongst tax practitioners seems to be that "freezes" should be done as expeditiously as possible and with given flexibility that can be built into the "freeze" company and that in most cases the advantages far outweigh the disadvantages. It is, of course, necessary to look at the client's individual situation before deciding.

It is readily apparent that the valuation of assets is an essential ingredient insofar as estate planning and administration of estates is concerned. The valuation of things is not the function of a lawyer but rather that of valuators skilled in the particular area in question. It is, however, very much a lawyer's function to assist his clients in

(a) the interpretation of valuator's reports,

(b) the comparison of valuator's reports,

(c) the presentation of the opinions of valuators on behalf of clients either in the form of

(i) oral or written submissions to taxing authorities, or

(ii) oral or written evidence and submissions before courts or other tribunals,

(d) the cross-examination of expert valuators giving evidence on the other side. 
The Income Tax Act is rife with references to "fair market value". Section 13(7) refers to "fair market value" as being deemed to have been paid or received in a number of situations where property has been acquired or disposed of. Section 69(1) deemed certain purchases and sales to have been effected at "fair market value" regardless of the factual consideration paid. Inventory for income purposes is also to be valued at the lower of costs or "fair market value".15 Where property of a corporation has been appropriated to one or more of its shareholders for less than its full value, section $15(1)$ can be applied to require the inclusion in income of an amount equal to the "value" of such property. In addition, in such circumstances the corporation is deemed to have disposed of such property at its "fair market value" as prescribed by section $69(4)$.

Thus, it is seen that while the legal profession does not attempt to hold itself out as valuators its practitioners must have a working knowledge of what valuation reports mean. The Royal Commission on Taxation, in referring to fair market value, cited the frequently quoted definition as follows: ${ }^{16}$

By fair market value it is meant the amount of money which a purchaser willing but not obliged to buy the property would pay to an owner willing but not obliged to sell it.

The Supreme Court of Canada has held in the case of Untermeyer v. A.G. of B.C.17 that it is doubtful that "fair" adds anything to the meaning of the words "market value" except possibly to the extent that market price must have some consistency and not be due to the effect of a transient boom or sudden panic in the market.

Although valuation is frequently described as an art rather than a science, it is not a completely unprincipled art. There have been developed some broad guidelines which are worth considering in valuation matters.

Price cannot always be equated with value. The latter has been defined by the Carter Commission Report, to which I have referred. Prices paid for securities traded on a public stock exchange may be influenced by a great many factors, some of which may have absolutely no bearing on a proper appraisal of the value of such securities.

An option price is of little use in determining value. It is a onesided arrangement. It is reasonable to expect it will not be exercised if the value of the property subject to the option is less than the option price. Evidence of arms length sales effected shortly after the appropriate valuation day may be significant indications of value although, once again, it must not be construed as being conclusive. In valuing a business for the purposes of estate planning or filing the necessary returns upon death the following are some factors which must be considered:

(a) 1971 undistributed income on hand,

(b) tax paid undistributed surplus on hand,

(c) 1971 capital surplus,

(d) capital dividend account,

(e) post-1971 surplus,

(f) paid up capital and paid up capital deficiencies,

15 Income Tax Act, supra, n. 1 s. 10(1).

16 Report on the Royal Commission on Taxation 1966, Vol. 3 at 500.

17 (1929) S.C.R. 84. 
(g) designated surplus,

(h) refundable taxes.

A book recently published by Mr. George Ovens entitled Business and Security Valuation is an excellent authority and one which should be on the shelves of most lawyers. 18

From the above it is, I hope, obvious that rather than making estate planning redundant, the new legislation has made it all the more vital. If the legal profession is to retain its traditional role of estate advisors, will draftsmen and probate practitioners, a working knowledge of these new concepts and problems is essential. All too often we as a profession have "backed away" from new emerging areas of the law. If we continue to do this in the estate area we will soon find that others will step in and we shall cease to be recognized as competent advisors in this vital area. The challenge is there-let us hope we meet it well. 